\title{
Mænuskaði af völdum slysa á Íslandi á árunum 1975-2014
}

\author{
Eyrún Arna Kristinsdóttir ${ }^{1}$ æknanemi, Sigrún Knútsdóttir ${ }^{2}$ sjúkrapjálfari, Kristinn Sigvaldason ${ }^{3}$ læknir, \\ Halldór Jónsson jr. ${ }^{1,4}$ læknir, Páll E. Ingvarsson ${ }^{1,2}$ læknir
}

\section{Á G R I P}

\begin{abstract}
Inngangur: Mænuskaði er meðal alvarlegustu afleiðinga slysa og par sem ekki hefur tekist að finna lækningu við mænuskaða hefur áhersla verið lögð á forvarnarstarf. Nýgengi mænuskaða er breytilegt milli landa og ýmsar breytingar hafa orðið á faraldsfræði mænuskaða í áranna rás. Markmið pessarar rannsóknar var að kanna faraldsfræði mænuskaða af völdum slysa á Íslandi og leita áhættupátta sem nýta mætti í forvarnarskyni.
\end{abstract}

Efniviður og aðferðir: Farið var afturskyggnt yfir sjúkraskrár allra sem greindust með mænuskaða samkvæmt ICD-9/ICD-10 á Landspítala á árunum 1975-2014. Upplýsinga var aflað um nýgengi, aldur, kynjaskiptingu og orsakir. Notaður var skalinn American Spinal Injury Association Impairment Scale (AIS) við mat á alvarleika mænuskaða.

Niðurstöður: Á rannsóknartímabilinu hlutu 233 einstaklingar mænuskaða af völdum áverka, eða 26 á hverja milljón íbúa á ári að međaltali. Karlmenn voru $73 \%$ og meðalaldurinn 39 ár. Umferðarslys voru algengasta orsök mænuskaða. Oftast var um að ræða bílveltur í dreifbýli og i að minnsta kosti helmingi tilfella voru bílbelti ekki notuð. Fall var næstalgengasta orsök mænuskaða en í peim orsakaflokki var meðalaldurinn hæstur. Reiðmennsku- og vetrarípróttaslys voru algengust íprótta- og tómstundaslysa. í um priðjungi mænuskaðatilfella var um að ræða alskaða á mænu. Við útskrift höfðu $9 \%$ náð fullum bata.

Ályktun: Mikilvægt er að efla enn frekar forvarnir og áróður í tengslum við bílbeltanotkun og öryggi á vegum landsins. Einnig parf að leita leiða til að fækka mænuskaðatilfellum vegna falls, svo sem með pví að kanna nánar ástæður falla hjá eldra fólki og bæta öryggisreglur á vinnustöðum. Hugsanlega mætti fækka íprótta- og tómstundaslysum með forvarnaraðgerðum og bættum öryggisbúnaði.

\section{Inngangur}

Mænuskaði er meðal alvarlegustu afleiðinga slysa og getur haft mikil áhrif á líf hins slasaða, fjölskyldu hans og samfélagið í heild. Oftast er petta varanlegur skaði og sá sem í hlut á getur purft að reiða sig á heilbrigðiskerfið og félagsmálayfirvöld með marga eða alla pætti daglegs lífs til æviloka. Mænuskaði hefur oft mikil áhrif á andlega líðan einstaklingsins auk pess sem álagið á fjölskyldu hans getur orðið mikið. Endurhæfing er mikilvæg til að gera hinn mænuskaðaða eins sjálfbjarga og unnt er og bæta lífsgæði hans. Par sem ekki hefur tekist að finna lækningu við mænuskaða prátt fyrir miklar rannsóknir hefur áhersla verið lögð á forvarnarstarf til að fyrirbyggja pessa áverka.

Niðurstöður faraldsfræðirannsóknar frá árinu 2006 sýndu mjög breytilegt nýgengi mænuskaða milli landa eða allt frá 10,4 (Holland) upp í 83 tilfelli (Alaska) á hverja milljón íbúa. Algengast var bó að nýgengið væri á bilinu 15-30 á hverja milljón íbúa. ${ }^{1}$ Samkvæmt samantekt á faraldsfræði mænuskaða sem gerð var árið 2014 var alpjóðlegt nýgengi árið 2007 áætlað 23 á hverja milljón íbúa² sem er í góðu samræmi við rannsóknina frá 2006.

Niðurstöður rannsókna víða að úr heiminum hafa sýnt breytingar á ýmsum páttum varðandi faraldsfræði mænuskaða í

\footnotetext{
'Læknadeild Háskóla Íslands, ²endurhæfingardeild Landspítala Grensási,

${ }^{3}$ svæfinga- og gjörgæsludeild, ${ }^{4}$ bæklunarskurðdeild Landspítala.

Fyrirspurnum svarar Páll E. Ingvarsson, palling@/andspitali.is

Höfundar hafa útfyllt eyðublað um hagsmunatengsı.

https://doi.org/10.17992/lbl.2016.11.106
}

Greinin barst 25. febrúar 2016, sampykkt til birtingar 27. september 2016. áranna rás. ${ }^{3-6}$ Má par einna helst nefna hækkandi meðalaldur slasaðra en samkvæmt bandarískum gagnagrunni frá 1973, National Spinal Cord Injury Database (NSCID), sem inniheldur gögn um 22.000 mænuskaðasjúklinga, hækkaði meðalaldurinn um 9 ár milli tímabilanna 1973-1979 og 2000-2003.3,7 Aldursdreifingin er nú orðin tvítoppa, stærsti aldurshópurinn er víðast hvar ennpá ungt fólk sem oftast hefur slasast í umferðarslysum en aldurshópurinn $\geq 65$ ára er stækkandi og meðal peirra er fall algengasta orsökin. ${ }^{4}$ Mænuáverkum af völdum falla virðist fara fjölgandi og sums staðar er fall orðið veigameiri orsök en umferðarslys sem voru lengi vel algengasta orsök mænuskaða í vestrænum löndum. - $-5,8-12^{\text {Karl- }}$ menn eru enn í meirihluta peirra sem fá mænuskaða en hlutfall kvenna hefur verið að aukast undanfarna áratugi. Samkvæmt NSCID-gagnagrunninum jókst hlutfall kvenna úr 18,2\% í kringum 1970 í 21,8\% um 2000 og var munurinn marktækur. ${ }^{3}$

Frá árslokum 1973 hafa nánast undantekningarlaust allir með mænuskaða á Íslandi legið á Landspítala og fengið endurhæfingarmeðferð á Grensásdeild Landspítala í kjölfarið og gefst pví einstakt tækifæri til að gera ítarlega rannsókn á faraldsfræði mænuskaða á Íslandi. Stuðst var að hluta við gögn úr fyrri rannsókn á faraldsfræði mænuskaða á Íslandi á árunum 1975-2009 en niðurstöður hennar voru birtar árið 2012. ${ }^{6}$ Markmið pessarar rannsóknar var að afla upplýsinga um nýgengi, algengi, orsakir, aldur, kynjaskiptingu og alvarleika mænuskaða á Íslandi á 40 ára tímabili (1975-2014) og kanna hvort hægt væri að finna einhverja áhættupætti mænuskaða og bera kennsl á áhættuhópa en slíkar upplýsingar eru grundvöllur forvarnarstarfs. 


\section{Efniviður og aðferðir}

Sjúkragögn allra sem greinst höfðu með mænuskaða á árunum 1975-2014 samkvæmt International Classification of Diseases (kóðar 806-806.9, 952 og 953 í ICD-9 og S14-S14.6 í ICD-10) voru yfirfarin með tilliti til aldurs, kyns, orsaka og alvarleika mænuskaðans. Peir einstaklingar sem létust áður en peir komust á sjúkrahús og peir sem eingöngu höfðu hlotið áverka á taugarót voru undanskildir úr rannsóknarhópnum.

Við flokkun á orsökum mænuskaða var notast við alpjóðlegt flokkunarkerfi, International Spinal Cord Injury Core Data Set, en samkvæmt pví skal flokka orsakirnar í íprótta- og tómstundaslys, líkamsárásir, flutningsslys (svo sem umferðarslys og flugslys), fall og loks aðrar orsakir. ${ }^{13}$ Flokkunarkerfinu var pó ekki fylgt nákvæmlega par sem líkamsárásir eru mjög sjaldgæf orsök mænuskaða hér á landi og voru pær pví hafðar undir yfirflokknum annað. Einnig ættu flugslys tæknilega séð að flokkast undir flutningsslys en pau voru höfð í yfirflokknum annað af sömu ástæðu. Að auki voru skoðaðir helstu undirflokkar pessara orsaka, svo sem ólíkar gerðir umferðarslysa og íprótta- og tómstundaslysa. Fall var flokkað í lágt fall (<1 m), hátt fall (1-5 m) og háorkufall (>5 m) og kannað var hvort um væri að ræða vinnuslys. Fyrir pá sem hlutu mænuskaða vegna umferðarslysa var leitað upplýsinga um bílbeltanotkun og athugað hvort slysin hefðu orðið í péttbýli eða dreifbýli.

Við mat á alvarleika mænuskaða var notaður kvarðinn American Spinal Injury Association Impairment Scale (AIS) en samkvæmt honum er mænuskaði flokkaður frá A til E par sem A er alskaði á mænu en B, C og D eru misalvarlegar gerðir hlutskaða. Við hlutskaða er skyn varðveitt að hluta til en hreyfigeta er ýmist engin (gerð B), verulega skert (gerð C) eða vægt skert (gerð D). ${ }^{14}$ Einstaklingar með mænuskaða af gerð A, B og C verða háðir hjólastól en hreyfifærni og sjálfsbjargargeta peirra fer pó eftir umfangi og hæð skaðans. Meirihluti peirra sem eru með mænuskaða af gerð D endurheimta hæfnina til að geta gengið með eða án hjálpartækja. ${ }^{15}$ Peir sem endurheimta skyn og hreyfigetu að fullu í kjölfar mænuskaða teljast með gerð E. ${ }^{14}$

\section{Tölfræðiúrvinnsla}

Gögnum var safnað í Excel (C 2015 Microsoft) og tölfræðiúrvinnsla fór fram í tölfræðiforritinu R (๑ The R Foundation). Notað var stikapróf (parametric tests) til að lýsa normaldreifðum gögnum

Tafla I. Fjöldi einstaklinga og árlegt nýgengi skoðað fyrir hvert 5 ára tímabil.

\begin{tabular}{lcc}
\hline Árabil & $\begin{array}{c}\text { Fjöldi með mænuskaða } \\
(\mathrm{n}=233)\end{array}$ & $\begin{array}{c}\text { Árlegt nýgengi á hverja } \\
\text { milljón íbúa }\end{array}$ \\
\hline $1975-1979$ & 33 & 30 \\
\hline $1980-1984$ & 21 & 18 \\
\hline $1984-1985$ & 28 & 23 \\
\hline $1989-1990$ & 26 & 20 \\
\hline $1994-1999$ & 17 & 13 \\
\hline $2000-2004$ & 30 & 21 \\
\hline $2005-2009$ & 52 & 34 \\
\hline $2010-2014$ & 26 & 16 \\
\hline
\end{tabular}

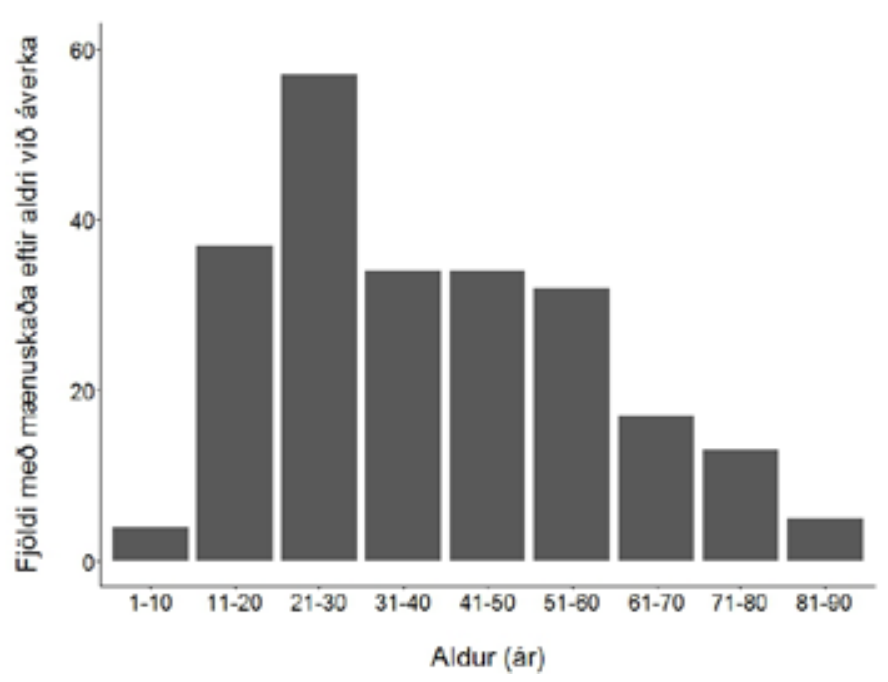

Mynd 1. Fjöldi einstaklinga með mænuskaða af völdum áverka í hverjum aldursflokki.

og meðaltöl tveggja hópa voru borin saman með t-prófi. Meðalaldur er sýndur ásamt lægsta og hæsta aldri innan hvers hóps. Pegar bera átti saman hlutfallslegan mun ólíkra hópa var kí-kvaðrat próf notað. Tölfræðileg marktækni var miðuð við p-gildi <0,05.

\section{Niðurstöður}

Nýgengi ásamt aldurs- og kynjadreifing

Á rannsóknartímabilinu fengu alls 233 einstaklingar mænuskaða af völdum áverka. Í töflu I má sjá nýgengi mænuskaða fyrir hvert 5 ára tímabil. Aukning varð á nýgenginu á árunum 2005-2009 en á pví árabili var nýgengið hæst, eða 34 á hverja milljón íbúa. Nýgengið lækkaði svo aftur niður í 16 á hverja milljón íbúa á síðustu 5 árunum.

Rannsóknarhópurinn samanstóð af 171 karlmanni (73\%) og 62 konum (27\%). Meðalaldurinn var 39 ár (4-83) og ekki var marktækur munur á meðalaldri kynjanna $(\mathrm{p}=0,77)$. Mynd 1 sýnir fjölda einstaklinga í hverjum aldursflokki en eins og sést par var aldursflokkurinn 21-30 ára fjölmennastur með 57 einstaklinga. Pegar rannsóknartímabilið var skoðað í heild reyndist meðalaldur mænuskaðaðra hækka marktækt frá upphafi til enda $(\mathrm{p}=0,002)$ en pó voru talsverðar sveiflur á meðalaldri milli tímabila (mynd 2). Rúmur helmingur kvennanna slasaðist eftir árið 2000 en pó varð ekki marktæk aukning á hlutfalli kvenna á rannsóknartímabilinu $(\mathrm{p}=0,667)$. Í öllum aldursflokkum voru karlmenn í meirihluta að undanskildum aldursflokkinum 1-10 ára en í honum voru tveir drengir og tvær stúlkur.

\section{Orsakir}

Í töflu II má sjá helstu orsakir mænuskaða á rannsóknartímabilinu ásamt meðalaldri, hlutfalli >60 ára og kynjahlutföllum í hverjum orsakaflokki. Eins og sést voru umferðarslys algengasta orsök mænuskaða $(40 \%, \mathrm{n}=94)$. Flest umferðarslys voru bílslys $(90 \%$, $\mathrm{n}=85)$ en aðrar gerðir umferðarslysa voru vélhjólaslys (9\%, n=8) og reiðhjólaslys (1\%, n=1). Meðal bílslysa voru bílveltur algengastar $(58 \%, n=49)$ en árekstur var orsökin í 15 tilfellum (18\%) og útafkeyrsla í 14 (16\%). I 5 bílslysum (6\%) var um að ræða slys á gangandi 


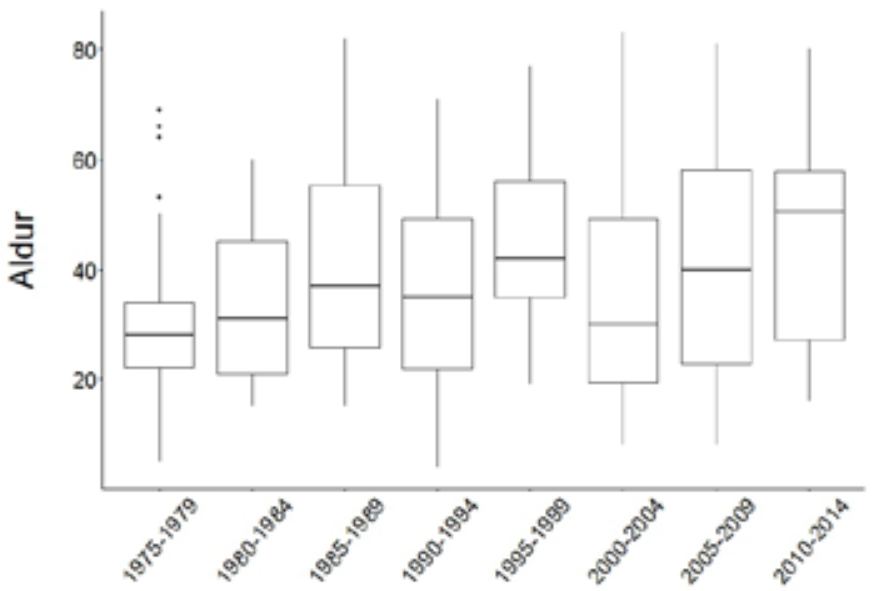

Ár

Mynd 2. Meðalaldur peirra sem fengu mænuskaða af völdum áverka skoðaður fyrir hvert 5 ára tímabil.

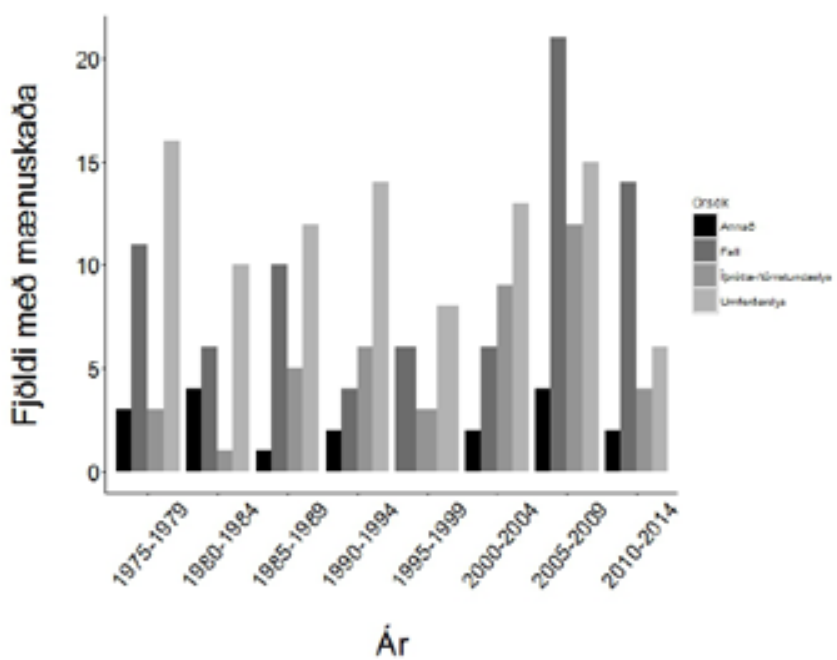

Mynd 4. Fjöldi einstaklinga með mænuskaða af völdum áverka í hverjum orsakaflokki, skoðaður fyrir hvert 5 ára tímabil.

vegfaranda. Meirihluti bílslysa (83\%) varð í dreifbýli. Í að minnsta kosti helmingi tilfella $(51 \%, n=40)$ höfðu bílbelti ekki verið notuð en upplýsingar um bílbeltanotkun vantaði fyrir $28 \%$ (n=22). Í rúmum helmingi mænuskaðatilfella á árunum 1990-1994 var um að ræða bílslys en hlutfall bílslysa sem orsök mænuskaða hefur farið lækkandi undanfarin ár og á árunum 2010-2014 var pað 23\%.

Fall var næstalgengasta orsök mænuskaða $(34 \%, n=78)$. Hátt fall var heldur algengara $(38 \%, n=30)$ en lágt fall $(29 \%, n=23)$ og háorkufall (29\%, n=23). Upplýsingar um fallhæð vantaði í tveimur tilvikum (3\%). Meðalaldur peirra sem fengu mænuskaða vegna

Tafla II. Helstu orsakir mænuskaða, meðalaldur, kynjahlutfall og hlutfall >60 ára.

\begin{tabular}{lcccc}
\hline Orsakir & $\begin{array}{c}\text { Fjöldi } \\
(\mathrm{N}=233)\end{array}$ & $\begin{array}{c}\text { Meðalaldur } \\
(\text { ár) }\end{array}$ & $\begin{array}{c}\text { Kynjahlutfall } \\
\text { (karlar:konur) }\end{array}$ & $\begin{array}{c}\text { Hlutfall }> \\
60 \text { ára (\%) }\end{array}$ \\
\hline Umferðarslys & $94(40 \%)$ & 33 & $2,2: 1$ & 9 \\
\hline Fall & $78(34 \%)$ & 47 & $4,2: 1$ & 28 \\
\hline $\begin{array}{l}\text { Íprótta- og } \\
\text { tómstundaslys }\end{array}$ & $43(18 \%)$ & 39 & $1,7: 1$ & 9 \\
\hline Annað & $18(8 \%)$ & 35 & $8: 1$ & 6 \\
\hline
\end{tabular}

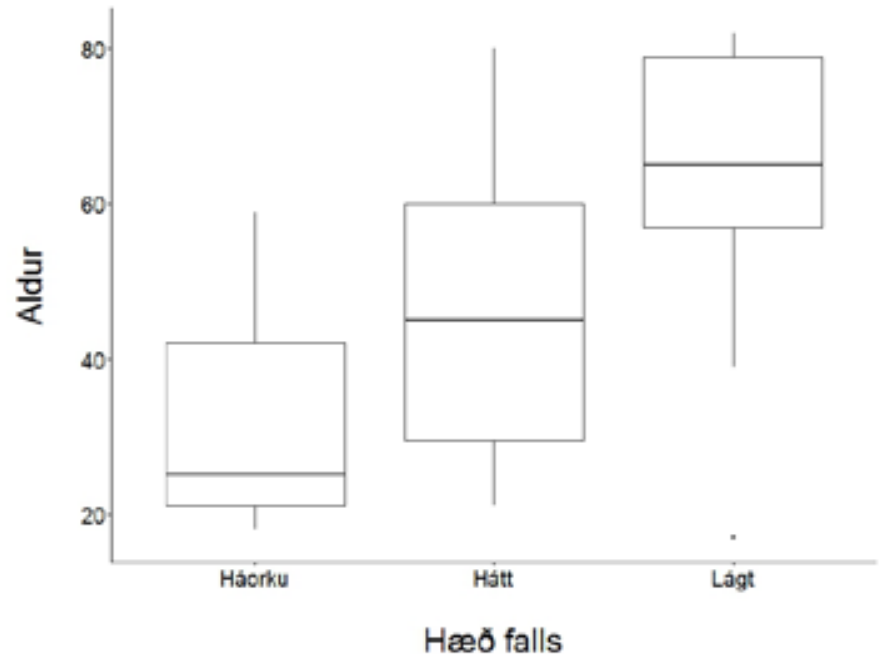

Mynd 3. Meðalaldur peirra sem fengu mænuskaða vegna falls skoðaður með tilliti til fallhæðar.

falls var marktækt hærri en peirra sem slösuðust af öðrum orsökum $\left(\mathrm{p}=1,5 \times 10^{-5}\right)$, eða 47 ár. Fall var algengasta orsök mænuskaða hjá fólki eldra en 60 ára (63\% tilfella í peim aldursflokki). Einnig var marktækur munur á meðalaldri eftir pví hver fallhæðin var (mynd 3). Í $18 \%$ ( $n=14)$ mænuskaðatilfella vegna falls var um vinnuslys að ræða og flest peirra urðu í byggingariðnaði. Fimm pessara vinnuslysa (36\%) urðu á tímabilinu 2005-2009. Aukning varð á fjölda mænuskaða vegna falls milli árabilanna 2000-2004 (20\%, n=6) og 2005-2009 $(40 \%, n=21)$ (mynd 4) og var munurinn marktækur $(\mathrm{p}=0,001)$. Hlutfall falla sem orsök mænuskaða var enn hátt á síðustu 5 árunum $(54 \%, \mathrm{n}=14)$.

Á rannsóknartímabilinu hlutu 43 einstaklingar (18\%) mænuskaða vegna íprótta- eða tómstundaslysa. Algengust peirra voru hestaslys $(37 \%, \mathrm{n}=16)$ en í peim og skíðaslysum hlutu fleiri konur en karlar mænuskaða. Vetrarípróttaslys, svo sem vélsleðaslys og skíðaslys, voru $21 \%$ ( $n=9$ ) íprótta- og tómstundaslysa. Sem dæmi um aðrar orsakir má nefna dýfingaslys $(n=5)$, svifflugsslys $(n=4)$, fimleikaslys $(n=2)$ og fjórhjólaslys $(n=2)$. Rúmur helmingur $(58 \%$, $\mathrm{n}=25$ ) íprótta- og tómstundaslysa varð eftir síðustu aldamót en á árunum 2000-2004 voru slík slys orsök mænuskaða í 30\% tilfella $(\mathrm{n}=9)$. Hlutfallið hefur farið lækkandi síðan pá en pað var $23 \%$ $(\mathrm{n}=12)$ á árunum 2005-2009 og 15\% (n=4) á árunum 2010-2014.

Alvarleiki og umfang mænuskaða

Samkvæmt AIS-flokkunarkerfinu fyrir alvarleika mænuskaða var um að ræða alskaða, pað er gerð A, hjá 73 einstaklingum (31\%) við útskrift af sjúkrahúsi. Peir sem voru með hlutskaða á mænu voru 127 (55\%) en af peim voru 5 (4\%) með gerð B, 30 (24\%) með gerð C og 92 (72\%) með gerð D. Við útskrift hafði 20 einstaklingum (9\%) farið nógu mikið fram til að teljast með gerð E, pað er með eðlilegt skyn og fulla hreyfigetu. Alls létust 13 einstaklingar innan 30 daga (6\%), par af 11 innan 5 daga. Ekki var hægt að meta hæð eða alvarleika mænuskaða pessara einstaklinga.

Um helmingur ( $n=117)$ var með ferlömun (tetraplegia) við útskrift. Af peim voru 30\% (n=35) með alskaða á mænu en $60 \%(n=71)$ með misalvarlegar gerðir hlutskaða. Ellefu einstaklingar $(10 \%)$ 


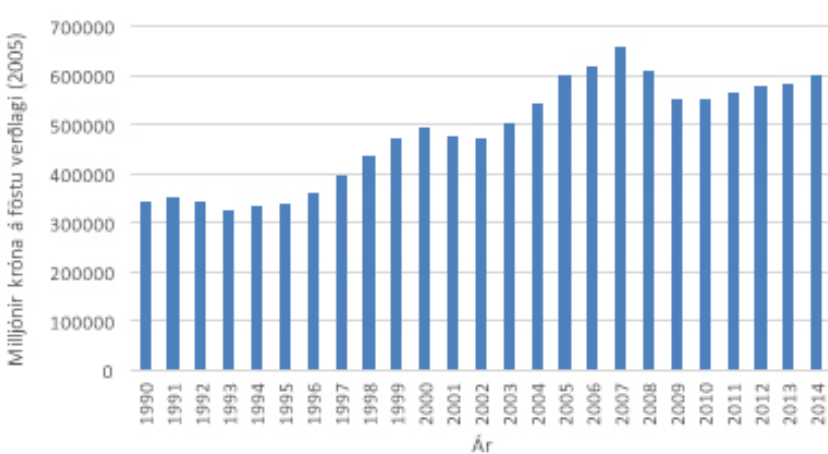

Mynd 5. Einkaneysla á Íslandi á árunum 1990-2014.

höfðu náð nógu miklum framförum hvað varðar skyn og hreyfigetu til að teljast með gerð E við útskrift. Umferðarslys voru orsök ferlömunar í 51 tilfelli (44\%) en fall var næstalgengasta orsökin $(32 \%, \mathrm{n}=38)$. Af peim sem voru með pverlömun (paraplegia) voru 37\% (n=38) með alskaða, 54\% (n=56) með hlutskaða og 9\% (n=9) með gerð E við útskrift. Meðal peirra voru umferðarslys (37\%, $\mathrm{n}=38)$ og föll $(36 \%, \mathrm{n}=37)$ algengustu orsakirnar.

\section{Umræður}

Á árunum 1975-2014 voru 233 einstaklingar lagðir inn á Landspítala með mænuskaða af völdum áverka. Landspítalinn pjónar stórhöfuðborgarsvæðinu en pangað eru einnig send alvarleg slys af landinu öllu og peir sem fá mænuskaða á Íslandi koma nánast undantekningarlaust til bráðameðferðar á Landspítala og fá endurhæfingarmeðferð á Grensásdeild í kjölfarið. Pví má ætla að rannsóknin nái til langflestra sem fengu mænuskaða á Íslandi á rannsóknartímabilinu og má pví í raun kalla rannsóknina lýðgrundaða. Ekki er pó hægt að útiloka með öllu að til séu dæmi um að vægur mænuskaði hafi verið meðhöndlaður á öðrum heilbrigðisstofnunum á landinu. Nýgengi mænuskaða á rannsóknartímabilinu var 26 tilfelli á hverja milljón íbúa að meðaltali en var pó mjög breytilegt milli tímabila eða allt frá 13 upp í 34 tilfelli á hverja milljón íbúa. Sá breytileiki skýrist líklega að einhverju leyti af smæð íslensku pjóðarinnar. Á árunum 2005-2009 sást langhæsta nýgengið sem var pá 34 tilfelli á hverja milljón íbúa.

Árlegt nýgengi mænuskaða hér á landi er mjög sambærilegt pví sem sást í Vestur-Noregi á 50 ára tímabili (1952-2001) sem var um 26,3 tilfelli á hverja milljón íbúa. ${ }^{12}$ Nýgengið í Svípjóð virðist heldur lægra en á Íslandi, en pað var 19,6 á hverja milljón íbúa á 13 mánaða tímabili á árunum 2006-2007.11 Sama má segja um nýgengið í Finnlandi en pað var 10 tilfelli á hverja milljón íbúa á árunum 1976-2005. ${ }^{10}$ Nýgengið hér á landi virðist einnig hærra en í Austurríki ${ }^{9}$ (17 tilfelli á hverja milljón íbúa á árunum 2002-2012) og Skotlandi ${ }^{14}$ (16 tilfelli á hverja milljón íbúa á árunum 1994-2013). Ekki er ljóst af hverju pessi munur stafar en mikilvægt er að hafa í huga að beinn samanburður á niðurstöðum pessara rannsókna er varhugaverður par sem pær höfðu sumar mismunandi inntökuskilyrði og voru ekki allar lýðgrundaðar. Nýgengi mænuskaða hér á landi virðist lægra en í Kanada ${ }^{8,16}$ og Bandaríkjunum ${ }^{3}$ par sem nýgengið er um 40 tilfelli á hverja milljón íbúa. Hugsanlega stafar pessi munur að einhverju leyti af pví að hlutfall ofbeldis-

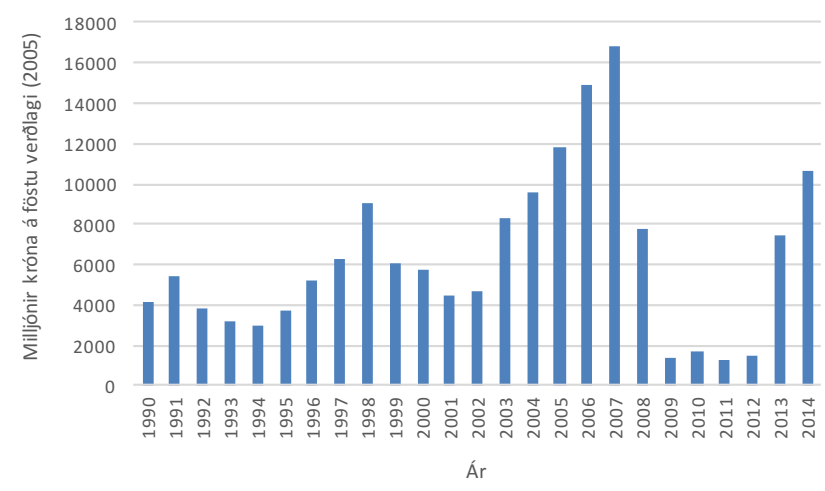

Mynd 6. Fjármunamyndun í mannvirkjagerd.

verka sem orsök mænuskaða í Bandaríkjunum og Kanada er hátt (17,8\% og 8,2\%) en á Íslandi hafa aðeins prír einstaklingar fengið mænuskaða af peim orsökum á síðastliðnum fjórum áratugum. ${ }^{3,8}$

Meðalaldur í rannsóknarhópnum var 39 ár (4-83) en pað er aðeins hærri meðalaldur en fram kemur í alpjóðlegri samantekt á faraldsfræði mænuskaða par sem meðalaldurinn var 33 ár. ${ }^{1}$ Pegar meðalaldurinn var skoðaður fyrir hvert 5 ára tímabil kom í ljós að hann jókst marktækt úr 31 í 47 ár á rannsóknartímabilinu. Pessar niðurstöður eru í samræmi við rannsóknir víða að úr heiminum sem sýna hækkandi meðalaldur peirra sem fá mænuskaða., ${ }^{3,4}$ Niðurstöður nýlegrar rannsóknar á faraldsfræði mænuskaða í Skotlandi sýndu hækkun á meðalaldri úr 44,1 í 52,6 ár á 20 ára tímabili (1994-2013). ${ }^{17}$ Orsakir pessarar hækkunar eru ekki pekktar en hana má að hluta skýra með hækkandi meðalaldri pjóðanna sem eiga í hlut. ${ }^{3}$

Vegna smæðar íslensku pjóðarinnar og par með rannsóknarhópsins er varhugavert að draga miklar ályktanir af breytingum á hlutfalli kvenna á rannsóknartímabilinu. Pó að munurinn hafi ekki reynst marktækur pegar rannsóknartímabilið var skoðað í heild má benda á að helmingur kvennanna slasaðist eftir árið 2000. Niðurstöður rannsóknar sem byggir á bandaríska NSCIDgagnagrunninum sýndu að hlutfall kvenna af peim sem slasast í umferðarslysum, ípróttaslysum og ekki síst peim sem tilheyra orsakaflokknum annað hefur hækkað. Pó telja höfundar jafnvel líklegra að pessi fjölgun kvenna í hópi peirra sem fá mænuskaða stafi af slysum sem verða hjá eldra fólki, til dæmis lágu falli, pví konur eru í meirihluta í eldri aldursflokkum bandarísku pjóðarinnar. ${ }^{3}$

Niðurstöður fjölpjóðlegrar samantektar á faraldsfræði mænuskaða frá árinu 2010 sýndu mjög breytileg hlutföll pverlömunar milli landa eða allt frá $19 \%$ og upp í $68 \%$ og pað sama gilti um ferlömun en par var hlutfallið 32-75\%. ${ }^{4}$ Á Íslandi var hlutfall pverlömunar og ferlömunar svipað. Fjölmennasti hópurinn reyndist samanstanda af einstaklingum sem hlutu ferlömun vegna hlutskaða á mænu en sá næstfjölmennasti af einstaklingum með pverlömun vegna hlutskaða. Svipaðar niðurstöður sáust í sambærilegri rannsókn frá Ástralíu. ${ }^{18}$ Samkvæmt nýlegri rannsókn frá Skotlandi reyndist hlutfall alskaða par vera lægra (um 30\%) en hér á landi og á Ítalíu og í Bandaríkjunum. Niðurstöður peirrar rannsóknar sýna einnig fjölgun mænuskaðatilfella af gerð C og D og telja höfundar ástæðuna vera aukinn fjölda mænuskaða vegna lágra falla meðal eldra fólks en peir áverkar eru oftast ekki eins alvarlegir og mænuáverkar af öðrum orsökum. ${ }^{17}$ Athyglisvert er 
að sjá að alls 20 einstaklingar (9\%) náðu nægilegum framförum í endurhæfingu til að teljast tilheyra flokki E við útskrift, pað er með eðlilegt skyn og fulla hreyfigetu.

Á Íslandi voru umferðarslys algengasta orsök mænuskaða pegar rannsóknartímabilið var skoðað í heild en hlutfall umferðarslysa hefur lækkað úr 54\% á árunum 1990-1994 í 23\% á árunum 2010-2014. Í meirihluta tilfella var um að ræða bílslys, oftast bílveltu í dreifbýli. Umferðarslys eru einnig algengasta orsök mænuskaða í Kanada, ${ }^{16}$ Bandaríkjunum $^{3}$ og Ástralíu ${ }^{18}$ en á Norðurlöndum er fall algengasta orsökin. ${ }^{10-12}$ Rúmlega helmingur peirra sem fékk mænuskaða vegna bílslyss var ekki í bílbelti en pað hlutfall gæti verið hærra par sem upplýsingar um bílbeltanotkun vantaði fyrir $28 \%$. Petta gefur ríka ástæðu að auka enn áróður fyrir notkun bílbelta.

Á árunum 2005-2009 sást mikil aukning falla sem orsök mænuskaða og voru pau algengasta orsök mænuskaða á síðasta áratug rannsóknartímabilsins. Ástæður pessarar aukningar eru ekki ljósar en skýrast hugsanlega af hækkandi meðalaldri peirra sem fá mænuskaða en fall var algengasta orsök mænuskaða hjá fólki eftir sextugt. Petta er í samræmi við upplýsingar úr bandaríska NSCIDgagnagrunninum. ${ }^{3}$ Fall er algengasta orsök mænuskaða í mörgum nágrannlöndum Íslands, pað er Svípjóð, ${ }^{11}$ V-Noregi, ${ }^{12}$ Finnlandi, ${ }^{10}$ Skotlandi ${ }^{17}$ og Austurríki. ${ }^{9}$

Höfundar hafa velt fyrir sér hugsanlegum orsökum pess að nýgengi mænuskaða á Íslandi jókst mikið á árunum 2005-2009. Samkvæmt upplýsingum frá Hagstofu Íslands eru pessar nýgengisbreytingar í samræmi við aukningu á einkaneyslu á pessu tímabili ${ }^{19}$ (mynd 5) sem gæti hafa leitt til aukinnar pátttöku fólks í frístundaiðkunum og aukningar á byggingaframkvæmdum (mynd 6). ${ }^{20}$ Á pessu tímabili sást fjölgun falla sem orsök mænuskaða sem gæti tengst aukningu á byggingaframkvæmdum en í peirri starfsgrein voru vinnuslys algengust. Upplýsingar úr Slysaskrá Íslands sýna að hlutfall vinnuslysa jókst á árunum 2003-2006 og náði hámarki árið 2006 pegar pað var um 20\% en fór svo lækkandi aftur. ${ }^{21}$ Á árunum 2005-2009 sást einnig fjölgun íprótta- og tómstundaslysa sem mætti hugsanlega rekja til breytts lífsstíls sem gæti tengst pessari hagfræðilegu uppsveiflu á Íslandi á tímabilinu. Pó er vert að nefna að á síðustu árum rannsóknartímabilsins sést einnig aukning á einkaneyslu og mannvirkjagerð án tilheyrandi aukningar á mænuskaðatilfellum. Jafnframt skýrir pessi hagfræðilega uppsveifla ekki hátt nýgengi mænuskaða á árunum 1975-1979 sem pá var 30 tilfelli á hverja milljón íbúa. Bent skal á að ökumönnum og farpegum var ekki gert skylt að nota öryggisbelti fyrr en árið 1981 og forvarnarumræða í tengslum við umferð var pá lítil sem engin. Einnig má ætla að ástand pjóðvega á Íslandi á peim árum hafi verið bágborið miðað við nú.

prátt fyrir að rannsóknarhópurinn hafi ekki verið sérlega stór, eykur óvenju langt rannsóknartímabil gildi rannsóknarinnar, ekki síst hvað varðar upplýsingar um mikilvægar breytingar á faraldsfræði mænuskaða á Íslandi undanfarna fjóra áratugi. Rannsóknin var afturskyggn en pví rannsóknarsniði fylgja ákveðnar takmarkanir. Sem dæmi má nefna skráningu bílbeltanotkunar, sem var mjög ábótavant, en fróðlegt hefði verið að sjá betur hversu margir peirra sem hlutu mænuskaða í bílslysi notuðu ekki bílbelti. Annað dæmi gæti verið rangt val á ICD-kóða sem mikilvægt er að hafa í huga við faraldsfræðilega samantekt eins og pessa.

Mænuskaði leiðir oftast til varanlegrar örorku og á meðan ekki finnst lækning parf að leita allra ráđa til að fyrirbyggja slys sem valda slíkum meiðslum. Faraldsfræðilegar rannsóknir sem pessi geta varpað ljósi á áhættuhópa og hugsanlega áhættupætti og gefið upplýsingar um á hvaða sviðum sé hægt að bæta aðbúnað og öryggi. Á grundvelli niðurstaðna pessarar rannsóknar er mikilvægt að efla forvarnir með áherslu á íprótta- og tómstundaslys, einna helst reiðmennsku og vetrarípróttir, en einnig er mikilvægt að auka enn frekar forvarnir og áróður í tengslum við notkun bílbelta og öryggi við akstur á pjóðvegum landsins. Jafnframt parf að leita leiða til að fækka mænuskaðatilfellum vegna falls, svo sem með pví að kanna nánar ástæður falla hjá eldra fólki og bæta enn frekar öryggisreglur á vinnustöðum. 


\section{Heimildir}

1. Wyndaele M, Wyndaele JJ. Incidence, prevalence and epidemiology of spinal cord injury: what learns a worldwide literature survey? Spinal Cord 2006; 44: 523-9.

2. Fitzharris M, Cripps RA, Lee BB. Estimating the global incidence of traumatic spinal cord injury. Spinal Cord 2014; 52: 117-22.

3. Jackson AB, Dijkers M, Devivo MJ, Poczatek RB. A demographic profile of new traumatic spinal cord injuries: change and stability over 30 years. Arch Phys Med Reh 2004; 85: 1740-8.

4. van den Berg ME, Castellote JM, Mahillo-Fernandez I de Pedro-Cuesta J. Incidence of spinal cord injury worldwide: a systematic review. Neuroepidemiol 2010; 34:1 84-92.

5. Bellucci $\mathrm{CH}$, Castro Filho JE, Gomes CM, Bessa Junior Jd, Battistella LR, Souza DR, et al. Contemporary trends in the epidemiology of traumatic spinal cord injury: changes in age and etiology. Neuroepidemiology 2015; 44: 85-90.

6. Knutsdottir $\mathrm{S}$, Thorisdottir $\mathrm{H}$, Sigvaldason $\mathrm{K}$, Jonsson $\mathrm{H}_{\text {, }}$ Jr., Bjornsson A, Ingvarsson P. Epidemiology of traumatic spinal cord injuries in Iceland from 1975 to 2009. Spinal Cord 2012; 50: 123-6.

7. DeVivo MJ, Chen Y. Trends in new injuries, prevalen cases, and aging with spinal cord injury. Arch Phys Med Rehab 2011; 92: 332-8.
8. Pirouzmand F. Epidemiological trends of spine and spinal cord injuries in the largest Canadian adult trauma center from 1986 to 2006. J Neurosurg Spine 2010; 12: 131-40.

9. Majdan M, Brazinova A, Mauritz W. Epidemiology of traumatic spinal cord injuries in Austria 2002-2012. Eur Spine J 2015; 25: 62-73.

10. Ahoniemi E, Alaranta H, Hokkinen EM, Valtonen K, Kautiainen $\mathrm{H}$. Incidence of traumatic spinal cord injuries in Finland over a 30-year period. Spinal Cord 2008; 46: 781-4.

11. Divanoglou A, Levi R. Incidence of traumatic spinal cord injury in Thessaloniki, Greece and Stockholm, Sweden: a prospective population-based study. Spinal Cord 2009; 47: 796-801.

12. Hagen EM, Eide GE, Rekand T, Gilhus NE, Gronning M. A 50-year follow-up of the incidence of traumatic spinal cord injuries in Western Norway. Spinal Cord 2010; 48: 313-8.

13. DeVivo $M$, Biering-Sorensen $F$, Charlifue $S$, Noonan $V$, Post M, Stripling T, et al. International Spinal Cord Injury Core Data Set. Spinal Cord 2006; 44: 535-40.

14. Maynard FM, Jr., Bracken MB, Creasey G, Ditunno JF Jr, Donovan $\mathrm{WH}$, Ducker TB et al. International Standards for Neurological and Functional Classification of Spinal Cord Injury. American Spinal Injury Association. Spinal Cord 1997; 35: 266-74
15. Consortium for Spinal Cord M. Outcomes following traumatic spinal cord injury: clinical practice guidelines for health-care professionals. J Spinal Cord Med 2000; 23 289-316.

16. Pickett GE, Campos-Benitez M, Keller JL, Duggal N. Epidemiology of traumatic spinal cord injury in Canada. Spine 2006; 31: 99-805.

17. McCaughey EJ, Purcell M, McLean AN, Fraser MH Bewick A, Borotkanics RJ et al. Changing demographics of spinal cord injury over a 20-year period: a longitudinal population-based study in Scotland. Spinal Cord 201; 54: 270-6.

18. O'Connor P. Incidence and patterns of spinal cord injury in Australia. Accid Anal Prev 2002; 34: 05-15.

19. Hagstofa Íslands. Einkaneysla 1990-2014. Viðmiðunartími: 1990-2014. hagstofa.is

20. Hagstofa Íslands, Borgartún 21a, 105 Reykjavík Ísland. Fjármunamyndun í mannvirkjagerð 1990-2014. Viðmiðunartími: 1990-2014. hagstofa.is.

21. Embætti landlæknis - Slysaskrá Íslands, Barónsstíg 47, 101 Reykjavík, Ísland. landlaeknir.is/tolfraedi-og-rannsoknir/ gagnasofn/gagnasafn/item12461/Slysaskra-Islands.

\section{ENGLISH SUMMARY}

\section{Epidemiology of Spinal Cord Injury in Iceland from 1975 to 2014}

Eyrún Arna Kristinsdóttir ${ }^{1}$, Sigrún Knútsdóttir², Kristinn Sigvaldason ${ }^{3}$, Halldór Jónsson jr. ${ }^{1,4}$, Páll E. Ingvarsson ${ }^{1,2}$

Introduction: Traumatic spinal cord injury (TSCl) is serious and often has long-term consequences. Since no cure has been found the emphasis has been on preventive measures. The incidence of $\mathrm{TSCl}$ varies between countries and the epidemiology has been changing. The aim of this study was to gather epidemiological data on patients with $\mathrm{TSCl}$ in Iceland and search for risk factors.

Material and methods: Hospital records of everyone diagnosed with TSCI in 1975-2014 admitted to Landspitali University Hospital were reviewed and information gathered on incidence, age, gender and causes of injury. The American Spinal Injury Association Impairment Scale (AIS) was used to assess the extent of TSCI.

Results: A total of 233 patients were diagnosed with TSCI during the study period or 26 per million annually on average. Males were $73 \%$ and the mean age was 39 years. Traffic accidents were the most common cause of TSCI. The majority were car rollovers in rural areas. Around $50 \%$ did not use a seatbelt. The second most common cause of TSCI were falls. The most common sport/leisure accidents were those related to horseback-riding and winter sports. A third of patients had a complete $\mathrm{SCl}$. At discharge $9 \%$ had gained full recovery.

Conclusions: Safe roads and good traffic culture are essential factors in the prevention of serious traffic accidents. Strict safety regulations in the work place and an investigation of causes of falls amongst the elderly could decrease SCls due to falls. Further preventive measures and protective equipment could possibly be of use in sport- or leisure-related activities.

Key words: Traumatic spinal cord injury, incidence, age, gender, causes, extent. 